\title{
Global Relapse in Lymph Nodes
}

National Cancer Institute

\section{Source}

National Cancer Institute. Global Relapse in Lymph Nodes. NCI Thesaurus. Code C159962.

Any new lymph node greater than $1.5 \mathrm{~cm}$ in the long axis in those with complete response proven to be N3 histologically. 